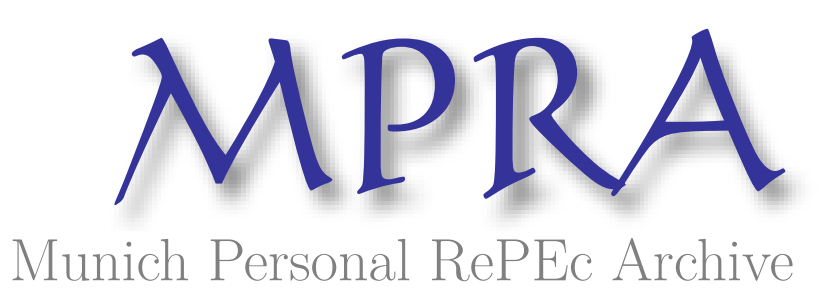

\title{
The pre- and post-crisis real exchange rate behavior in selected East Asian countries
}

\author{
Taguchi, Hiroyuki \\ Saitama University, Japan
}

2010

Online at https://mpra.ub.uni-muenchen.de/63789/

MPRA Paper No. 63789, posted 21 Apr 2015 18:56 UTC 


\title{
The Pre- and Post-crisis Real Exchange Rate Behavior in Selected East Asian Countries
}

\author{
Hiroyuki Taguchi* \\ *Director, Cabinet Office, Government of Japan
}

This article examines the real exchange rate behavior during the pre-crisis and post-crisis periods in selected East Asian countries by verifying its long-run stability through unit root tests, and investigates the interaction among the component variables of the real exchange rate, i.e. the exchange rate and the relative prices, by means of a vector autoregressive (VAR) model. The main findings of the study are as follows. First, the results of the unit root tests indicate the non-stationarity of the real exchange rate of each sample country during the pre-crisis period. Second, the test results show the stationarity of the real exchange rates in all the sample countries during the combined crisis and post-crisis period, although, during the post-crisis period alone, they do not always do so. Third, the results of the VAR model analyses reveal that most of the cases during the combined crisis and post-crisis period, covering all sample countries, support the Granger causality from the relative prices to the exchange rate and describe a significant, continuous effect of the relative prices on the exchange rate.

JEL classification: E44, F33

Key words: Real Exchange Rate Behavior, Pre-crisis and Post-crisis Periods, Stationarity of the Real Exchange Rates, VAR Model Analyses, Granger Causality from the Relative Prices to the Exchange Rate, U.S. Dollar Peg Regime 


\title{
The Pre- and Post-crisis Real Exchange Rate Behavior in Selected East Asian Countries
}

\author{
Hiroyuki Taguchi \\ Director, Cabinet Office, Government of Japan
}

\section{Introduction}

There is now a vast body of literature on the stability of the real exchange rate, which is equivalent to the validity of the purchasing power parity (PPP). Within this vast literature, professional opinion on both the short and long run appears to have shifted several times in the post-war period. At present, Taylor [14] (2003) concludes: "We seem to be moving back towards a consensus view that there is a tendency of the real exchange rate to converge on a level consistent with long-run PPP."

Most of the analyses in the literature have concentrated on the currencies of the major industrialized countries. Boyd and Smith [1] (1999) argue, however, that, in terms of both policy and methodology, the issue is more interesting for developing countries; in policy terms, exchange rate management is at the center of many financial stabilization policies, and in methodological terms, developing countries show more cross-section variation and more time-series noise. The 1997-98 Asian crises have also refocused attention on the real exchange rate behavior of East Asian countries. Most views expressed are critical of the pre-crisis de facto U.S. dollar peg regime, citing it as one cause of the crisis. It is said that this regime caused the appreciation of the real exchange rates and the subsequent loss of competitiveness.

Under this conditions, the empirical studies concerning with the stability of the real exchange rate of Asian countries have increased in recent years. Most of the previous studies have found no evidence or only weak evidence in favor of long-run PPP. For example, Baharumshah [2] (1997) shows that the PPP conditions observed in five Southeast Asian countries, namely Malaysia, Singapore, Thailand, the Philippines and Indonesia, were not consistent with the prediction of the PPP hypothesis during the period from the first quarter of 1974 to the fourth quarter of 1993. Hataiseree [7] (1995), through co-integration analysis, provides no evidence in support of a long-run equilibrium relationship between the nominal exchange rate for the Thai baht and the relative price ratio, thereby rejecting the idea of PPP during the period from November 1984 to June 1992.

Against this background, some studies have addressed the issue of structural breaks and have found some evidence in favor of PPP. Zurbruegg and Allsopp (2004) [15] use monthly data from 1990 to 2002 to explore the impact of the Asian crisis on the PPP 
relationship for Asian countries vis-à-vis the USA, and find evidence in favor of PPP for Japan, Korea, Malaysia, Singapore and Thailand after allowing for a single estimated break around the 1997 crisis in the cointegrating vector. Nusair (2004) [9], using quarterly data from the second quarter of 1973 to the first quarter of 2000, finds evidence of PPP vis-à-vis the USA for Indonesia, Korea, Malaysia and Thailand, after allowing for a break in the third quarter of 1997. The panel studies allowing for a single break, Breitung and Candelon (2005) [3] using monthly data from 1981 to 2001, and Wu et al. (2004) [16] using monthly and quarterly from 1980 to 2000, also find evidence in favor of PPP. Nusair (2008) [10], the latest study in the literature, re-examines the long-run PPP relationship for nine Asian countries relative to the USA and Japan, by utilizing a sophisticated method of the Johansen et al. (2000) [8] procedure that allows for up to two pre-determined structural breaks. The Johansen et al. procedure clearly provides strong support for long-run PPP for all the countries, regardless of the base country, except in the case of the Philippines vis-à-vis Japan.

This article examines the real exchange rate behavior during the pre-crisis and post-crisis periods in selected East Asian countries by verifying its long-run stability through unit root tests, and investigates the interaction among the component variables of the real exchange rate, i.e. the exchange rate and the relative prices, by means of a vector autoregressive (VAR) model applied to cases in which the long-run stability of the real exchange rate has been identified. In this context, the analysis strategy is to extend the studies of the long-run PPP relationship for Asian countries with a focus on the impact of a structural break of the Asian crises. This study, however, differs from the previous studies in the following aspects. First, it investigates the impact of the 1997 Asian crisis by means of splitting the sample into pre-crisis and post-crisis periods, and examines the effect of the exchange rate regime shifts from de facto U.S. dollar peg system to managed or freely floating one on the PPP relationship. The focus is, therefore, not on the identification of the long-run PPP during the entire periods but on the verification of the difference of PPP relationship between pre-crisis period and post-crisis period. Second, it analyses not only the long-run PPP relationship through unit root tests, but also the interaction - causality, variance decomposition and impulse-response - among the PPP component variables through VAR model. The following section is an empirical study, which includes methodology, data and discussions of the empirical results. The last section presents some concluding remarks.

\section{Empirical study}

We will now proceed to the empirical analysis. In order to select the sample countries for the analysis, we reviewed the chronologies of the exchange rate arrangements presented by Reinhart and Rogoff [12] (2002), which reclassified exchange rate regimes by employing newly complied monthly data sets on market-determined exchange rates. ${ }^{2}$ Among the chronologies, we focus on four countries which experienced the 1997-98 Asian crisis and 
altered their exchange rate regimes from the U.S. dollar peg system to a managed or freely floating system as a result of the crisis: Thailand, the Philippines, Indonesia and Korea. We exclude Malaysia, even though it did undergo the 1997-98 Asian crisis, because she has formally adopted the U.S. dollar peg system since 1998, after the crisis.

Focusing on the four sample countries, we first verify the long-run stability of the real exchange rates during the pre-crisis and post-crisis periods by applying the procedures of the augmented Dickey-Fuller (ADF) and the Philips-Perron (PP) tests to evaluate their stationarity. We next investigate the interaction among the component variables of the real exchange rate, i.e. the exchange rate and the relative prices, by means of a vector autoregressive (VAR) model applied to the cases where the long-run stability of the real exchange rate has been identified in the previous analysis.

\subsection{Verifying the long-run stability of the real exchange rate}

In this section, the ADF and PP tests are conducted in order to examine the stationarity of the real exchange rates in the sample countries during the pre-crisis and post-crisis periods. We first clarify the methodology and data in terms of the relationship between the real exchange rate and the purchasing power parity, the procedures of the ADF and PP tests, the specification of the real exchange rate and the real effective exchange rate, and the pre-and post-crisis period identification in view of the tests. Then, we discuss the test results.

\section{Methodology and data}

We first refer to the relationship between the real exchange rate and the purchasing power parity (PPP). The real exchange rate is an indicator of a country's international price competitiveness, specifically of a country's prices relative to those of other countries. It can also be expressed as the nominal exchange rate adjusted for relative national price level differences. We may formulate the real exchange rate, $z_{t}$, in logarithmic form as:

$$
z_{\dagger}=s_{\dagger}+p_{\dagger}-p^{*}{ }^{\prime}
$$

where $s_{t}$ is the nominal exchange rate, $p_{t}$ is the domestic price level, and $p^{*}$ is the foreign price level. On the other hand, the PPP exchange rate is the exchange rate between two currencies that would equate the two relevant national price levels if expressed in a common currency at that rate, so that the purchasing power of a unit of one currency would be the same in both economies. It may be formulated as:

$$
s_{\dagger}=p^{*}-p_{\dagger} .
$$

Comparing (1) and (2), we can see that, if the logarithm of the real exchange rate is identically equal to zero, PPP should hold. Thus, movements in the real exchange rate are tantamount to 
deviations from PPP. Further, an examination of the time-series properties of the real exchange rate may lead to the whole issue of whether or not the nominal exchange rate and relative national prices all settle down together at a level consistent with PPP in the long run. For the real exchange rate to settle down at any level whatsoever, it must display reversion towards its own mean. Hence, if the real exchange rate is mean-reverting, a necessary condition for long-run PPP to hold is satisfied. Generally, investigations of this issue have tested the null hypothesis of non-mean reversion against the alternative of mean reversion.

A staple statistics test for this purpose is the augmented Dickey-Fuller (ADF) test (Said and Dickey, [13] 1984) and the Philips-Perron (PP) [11] (1988) test for a unit root in the process driving the real exchange rate. The ADF test consists of running a regression of the first difference of the series against the series lagged once, lagged difference terms, and, optionally, a constant and a time trend. With two lagged difference terms, the regression is:

$$
\Delta \mathrm{z}_{\dagger}=\beta_{1} \mathrm{z}_{\mathrm{t}-1}+\beta_{2} \Delta \mathrm{z}_{\mathrm{t}-\mathrm{l}}+\beta_{3} \Delta \mathrm{z}_{\mathrm{t}-2}+\beta_{4}+\beta_{5} t .
$$

The PP test does not include lagged difference terms in the equation:

$$
\Delta \mathrm{z}_{\dagger}=\beta_{1} \mathrm{z}_{t-1}+\beta_{4}+\beta_{5}{ }^{t} .
$$

There are two choices to be made in running the regressions for both tests. One is whether or not to include a constant term in the regression. The other is whether or not to include a linear time trend. In each case, the test for a unit root is a test of the coefficient $z_{t-1}$ in the regression. The output of each test consists of the $t$-statistic of the coefficient $z_{t-1}$ and critical values for the test of a zero coefficient. If the coefficient is significantly different from zero, then the hypothesis that $z$ contains a unit root is rejected and the hypothesis that $z$ is stationary is not rejected. As explained by Corbae and Ouliaris [4] (1988), both procedures allow for fitted drift in the time-series model. The ADF test accounts for temporally dependent and heterogeneously distributed errors by including lagged innovation sequences in the fitted regression. In contrast, the PP test accounts for non-independent and identically distributed processes using a non-parametric procedure. Since the ADF relies on a parametric procedure to correct for autocorrelation and heterogeneity, the PP test is often favored over the ADF in terms of power.

We next discuss the issue of how to specify the real exchange rate defined above so as to calculate it. The real exchange rate is usually shown as a bilateral rate, like the nominal exchange rate. In general, the U.S. dollar is selected as the partner's currency. Then, Equation (1) may be rewritten as:

$$
Z_{t}\left(\text { US dollar / Local currency) }=S_{t}(\text { US dollar / Local currency })+p_{+}-p_{+} \text {uS } .\right.
$$


Since a country has so many trade partners and competitors in the world, the bilateral real exchange rates have to be unified in order to obtain a single indicator of a country's international price competitiveness. The real effective exchange rate (REER) is such an indicator. We can express the REER as the weighted average of the bilateral real exchange rates, as follows:

$$
R E E R_{\dagger}=W_{\text {US }} * Z_{\dagger}(\text { US dollar / Local currency })+W_{J P} * Z_{\dagger(\text { Japanese yen / Local currency })}+\cdots,(6)
$$

where $W_{u s}, W_{J P}, \ldots$ are the weights attached to each bilateral real exchange rate. The IMF weighting scheme is based on trade data for manufactured goods and primary goods, with the weights reflecting both the relative importance of a country's trading partners in its direct bilateral trade relations and that resulting from competition in third markets. ${ }^{3}$ Unfortunately, the REER compiled by the IMF based on this weighting scheme is not available except for the Philippines among our sample countries. An alternative way to unify the bilateral real exchange rates is to divide the U. S. dollar value of the price level of the country in question by the U. S. dollar value of the world export unit price index. This indicator, REER', is intended to denote price competitiveness: the prices of one country relative to those of the competitors in the world export markets. It can be written as:

$$
\text { REER }{ }_{\dagger}=S_{+}\left(\text {US dollar / Local currency) }+p_{+}-p_{+}\right. \text {WEUV }
$$

where $p_{t \text { WEUV }}$ denotes the world export unit value index on a U.S. dollar base. In the calculation above for the real exchange rate and the REER, we further need to clarify the price-level measurement. The price level is usually represented by the wholesale price index (WPI) or the consumer price index (CPI). The use of the WPI is generally favored as a measure of the real exchange rate, because, conceptually, the WPI is heavily weighted with tradable goods compared to the CPI, which measures price changes in both tradable and non-tradable items. However, the CPI has the advantage of being a base-weighted index designed to measure changes in the price level of an average broad basket of commodities in an economy, and of usually being more available when tracing back to past data. In our study, therefore, we use both the WPI and the CPI, since monthly data for these types of price index are available in the sample countries. Besides, this allows us to examine whether or not the choice of price index matters in the analysis of the real exchange rate. To sum up, we conduct the ADF and PP tests on the real exchange rate on a U.S. dollar base and the REER with the world export unit value index, each of which is calculated by using the WPI or the CPI as the price level index. The monthly data needed for these tests are taken from the International Financial Statistics (IFS) of the International Monetary Fund (IMF).

Lastly, we clarify the sample periods for the tests. In accordance with our analytical 
concern, we divide the period into a pre-crisis and a post-crisis period by referring again to the Reinhart and Rogoff [12] (2002) chronologies of the exchange rate arrangements of the sample countries. We assume that the pre-crisis period starts at the point when the U.S. dollar peg regime was adopted and ends at the point when that regime was abandoned under the Asian crisis. As for the post-crisis period, we describe it as following one of two patterns, according to whether or not it is combined with the turbulent crisis period. We assume that the combined crisis and post-crisis period would begin with the starting point of the "Freely falling" in the chronologies, and that the post-crisis period alone (without the crisis period) would begin from the point when the managed or freely floating arrangement is adopted after the crisis. The post-crisis period in both cases would continue until the present time, where data is available. To sum up, we conduct the ADF and PP tests for three kinds of periods: the pre-crisis period, the combined crisis and post-crisis period and the post-crisis period alone.

\section{Discussion of the empirical results}

Table 1 shows the results of the ADF and PP tests for the real exchange rates on a U.S. dollar base and the REER with the world export unit value index in the sample countries during the pre-crisis period, the combined crisis and post-crisis period, and the post-crisis period alone.

Table 1-1 lists the test results for the pre-crisis period. The results show that there is no case in which both the $\mathrm{ADF}$ and the PP test reject the null hypothesis of a unit root at the significance level of one to five percent. It suggests that, in all the sample countries, the real exchange rates and the REERs are non-stationary. On the other hand, Table 1-2 reveals that, in the combined crisis and post-crisis period, both tests do support the stationarity of the real exchange rates and the REERs with either the WPI or the CPI, as well as with either the intercept or trend and intercept. Table 1-3 indicates that, in the post-crisis period alone, both tests for the REERs reject the null hypothesis of a unit root with either the WPI or the CPI, as well as with either the intercept or trend and intercept, except in the case of the Philippines, whereas for the data series of the real exchange rate there is no case in which both tests reject it. To sum up, during the pre-crisis period, both the real exchange rate series and the REER series for all the sample countries indicate non-stationarity. During the combined crisis and post-crisis period, however, both series are stationary for all the sample countries, although during the post-crisis period alone they are not always so.

We may interpret the results above in the following way: during the pre-crisis period, the policy of the sample countries to stick to the U.S. dollar peg regime in their exchange rate management generated an upward trend of the real (effective) exchange rates leading to their non-stationarity, and during the post-crisis period, the sample countries, learning a lesson from the crisis, enhanced the flexibility of their exchange rates by rendering their exchange rate management more sensitive to the inflation gap, leading to the stationarity of the real (effective) exchange rates. It should also be noted that there are some differences in the test 
results, depending on whether or not the crisis period is combined with the post-crisis period. This may be due to the fact that the post-crisis period is too short to allow the judgment of the long-run stability of the real (effective) exchange rates of the sample countries.

\subsection{Examining the relationship between the exchange rate and the relative prices}

In the previous section, we verified the stationarity of the real (effective) exchange rates of the sample East-Asian countries during the combined crisis and post-crisis period. We speculated that the exchange rate management of the sample countries became more sensitive to the inflation gap as the pre-crisis period gave way to the post-crisis period. This may not be true, however, because the movement of the exchange rate, while being influenced by inflation, can also influence inflation. To what extent the exchange rate management has been affected by the inflation gap is also a question. This section aims at collecting the evidence to prove the causality from the relative prices to the exchange rate and to evaluate the degree of impact of the relative prices on the exchange rate by means of the analytical framework of the VAR model. We first explain the methodology and data, and then discuss the empirical results.

\section{Methodology and data}

The real exchange rate and the REER can be divided into the exchange rate and the relative prices. To be specific, the real exchange rate on a U.S. dollar base, as shown in Equation (5), is divided into $s_{t}$ of the exchange rate and $p_{t}-p_{t} U S$ of the relative prices, and the REER with the world export unit value in Equation (7) is divided into $s_{t}$ and $p_{t}-p_{t \text { WEUV. }}{ }^{4} \mathrm{We}$ focus on those cases discussed in the previous section where the stationarity of the real exchange rate and the REER with the WPI or the CPI as the relative prices during the combined crisis and post-crisis period was identified (i.e. the case of the REER of the Philippines with the WPI is excluded $)^{5}$. Concerning these cases, we examine the relationship between the exchange rate and the relative prices by means of a VAR model. The VAR model used here is composed of not only component variables of the real exchange rate and REER but also external balance variable, since the inclusion of external balance variable that has a short-run linkage with the real exchange rate makes the model more comprehensive. We use the ratio of the export value to the import value as a proxy of external balance variable because current balance data are not available on monthly base. Under the comprehensive VAR model estimation, we focus on the interaction between the exchange rate and the relative prices.

Before stepping into the VAR analysis, we test the stationarity of each data series by using the unit root tests of the ADF and PP tests. We construct a VAR model only if each of the variables is stationary. Therefore, the VAR model for the real exchange rate focuses on five cases: Thailand with the WPI, Indonesia with the WPI and the CPI, and Korea with the 
WPI and the CPI. The VAR model for the REER also focuses on five cases: Thailand with the WPI, the Philippines with the CPI, Indonesia with the WPI and the CPI, and Korea with the WPI. In constructing a VAR model, we have to specify the lag length according to some established criterion, since the results of the estimation are often sensitive to the lag length. For our choice of the optimal lag length (k) for the VAR model, we relied on the Akaike information criterion, the Schwarz information criterion and the Hannan-Quinn information criterion. Based on the test results, a lag length of $\mathrm{k}=2$ is deemed to be sufficient in all cases (the details of the test results are not reported here to conserve space).

By using the VAR model, we then conduct the following analyses that provide insight into the main channels of interaction among the variables in the system, i.e. the exchange rate and the relative prices: the Granger causality test, variance decomposition (VDC) and impulse-response analysis. The Granger [6] (1969) approach to the question of whether X causes $\mathrm{Y}$ is to see how much of the current $\mathrm{Y}$ can be explained by past values of $\mathrm{Y}$ and then to see whether or not adding lagged values of $\mathrm{X}$ can improve the explanation. $\mathrm{Y}$ is said to be Granger-caused by $\mathrm{X}$ if $\mathrm{X}$ helps in the prediction of $\mathrm{Y}$, or equivalently if the coefficients for the lagged X's are statistically significant. In the Granger causality test in a VAR model, the null hypothesis of the exclusion of the concerned variable in the equation is tested by the Wald statistic for the joint significance of the variable. The VDCs represent the proportion of the total variance of each variable that is attributable to each of the orthogonalized innovations. It measures the overall relative importance of an individual variable in generating variations due to its own shock as well as shocks due to other variables in the system. The impulse response functions (IRFs) trace the dynamic responses to the effect of a shock in one endogenous variable on all the endogenous variables in the system. In other words, IRFs map out the dynamic response path of a variable due to a one-period standard deviation shock to another variable.

To sum up, the analyses of Granger causality, VDCs and IRFs by means of a VAR model are conducted, in order to examine the interaction among the exchange rate and the relative prices, focusing on those cases where the stationarity of the real exchange rate and the REER during the combined crisis and post-crisis period was identified in the previous section, and also where the stationarity of each of component variables in the VAR model will be verified in this section. The major concern in these analyses is to prove the causality from the relative prices to the exchange rate and to determine the degree of impact of the relative prices on the exchange rate. As in the previous section, the monthly data needed for these analyses are taken from the IFS of the IMF.

\section{Discussion of the empirical results}

The results of the Granger causality test based on the VAR model above are given in Appendix 1. There are four cases (out of five) in which the VAR model for the real exchange rate yields the Granger causality from the relative prices to the exchange rate at standard 
significant levels: Thailand with the WPI, Indonesia with the CPI, and Korea with the WPI and the CPI. There are three cases (out of five) in which the model for the REER yields the same Granger causality: Thailand with the WPI, the Philippines with the CPI, and Korea with the WPI. On the other hand, in all but the case of the CPI for the Philippines under the REER VAR model, the exchange rate Granger-causes the relative prices. It may be a notable observation that, in all the sample countries, the Granger causality from the relative prices to the exchange rate was identified with either the WPI or the CPI under either the VAR model for the real exchange rate or the one for the REER.

The outcomes of the VDC analysis are presented in Appendix 2 for each VAR model. The relative prices explain 6 to 32 percent of the variance in the exchange rate after 20 months in six cases: Thailand with the WPI, Indonesia with the CPI, and Korea with the WPI under the VAR model for the real exchange rate, and Thailand with the WPI, the Philippines with the CPI, and Korea with the WPI under the VAR model for the REER, out of the seven cases in which the Granger causality from the relative prices to the exchange rate was identified. In the three cases where the Granger causality from the relative prices to the exchange rate was not identified, less than 3 percent of the variance in the exchange rate is accounted for by the relative prices. On the other hand, in all but the case of the Philippines with the CPI under the REER VAR model, the exchange rate explains more than 30 percent of the variance in the relative prices over a period of 20 months. Similarly to the test results for the Granger causality, a noteworthy result of the VDC analysis appears to be that, in all sample countries, the relative prices play a significant role in explaining the exchange rates when using either the WPI or the CPI under either the VAR model for the real exchange rate or that for the REER.

Appendix 3 shows the dynamic response pattern of the exchange rate to innovation in the relative prices by using the IRFs in the constructed VAR model. It reveals that the shock seems to have a positive and permanent effect in each case. Especially, in the cases where the Granger causality from the relative prices to the exchange rate was identified, the lagged effects tend to reach a certain point and level off after 12 to 18 months.

Table 2 summarizes the results of the analyses conducted above. To sum up, we first constructed a comprehensive VAR model for the ten cases where the stationarity of each variable was verified, out of the 15 cases where the stationarity of the real exchange rate and the REER during the combined crisis and post-crisis period was identified (the case of the Philippines with the WPI for the REER VAR model was excluded). Among the ten VAR models, seven cases, covering all the sample countries, showed the Granger causality from the relative prices to the exchange rate, and six out of the seven cases above, also covering all the sample countries, showed a significant, continuous effect of the relative prices on the exchange rate according to the VDC and IRF analyses. At the same time, it should be noted that nine of the ten VAR models also showed the Granger causality from the exchange rate to the relative prices (i.e. the reverse), and indicated a more dominant effect of the exchange rate 
on the relative prices than that of the relative prices on the exchange rate.

\section{Concluding remarks}

In this article, we set out to examine the real exchange rate behavior during the pre-crisis and post-crisis periods in selected East Asian countries. We applied the ADF and PP procedures to test the stationarity of the real exchange rates in order to verify their long-run stability. We then investigated the interaction among the component variables of the real exchange rate, i.e. the exchange rate and the relative prices, by means of a vector autoregressive (VAR) model in those cases where the long-run stability of the real exchange rate was identified. The key question was whether or not the exchange rate management of crisis-stricken East Asian countries from the pre-crisis period to the post-crisis period has found another path to follow by learning a lesson from the crisis.

The main findings of the study are as follows. First, during the pre-crisis period, the results of the ADF and PP tests indicate a unit root in the process driving the real exchange rate and the REER of each sample country, i.e. the non-stationarity of each series. Second, during the combined crisis and post-crisis period, on the contrary, the results of both tests show the stationarity of the real exchange rates and the REERs in all the sample countries, although during the post-crisis period alone they do not always do so. Third, the results of the VAR model analyses, focusing on the cases in which the stationarity of the real exchange rate and the REER during the combined crisis and post-crisis period was identified, reveal that most of the cases, covering all the sample countries, show the Granger causality from the relative prices to the exchange rate and describe a significant, continuous effect of the relative prices on the exchange rate according to the VDC and IRF analyses.

We may, therefore, interpret the results above in the following way: during the pre-crisis period, the policy of the sample countries to stick to the U.S. dollar peg regime in their exchange rate management generated an upward trend of the real (effective) exchange rates, leading to their non-stationarity, and during the post-crisis period, the sample countries, learning a lesson from the crisis, enhanced the flexibility of their exchange rates by rendering their exchange rate management more sensitive to the inflation gap, leading to the stationarity of the real (effective) exchange rates. The post-crisis period, however, seems to be too short to allow the judgment of the long-run stability of the real (effective) exchange rates, since there are some differences in the test results depending on whether or not the crisis period is combined with the post-crisis period. We will, therefore, need to re-analyze to obtain more consolidated results by keeping track of the upcoming data. 


\section{References}

[1] Boyd, Derick and Ron Smith, "Testing for Purchasing Power Parity: Econometric Issues and an Application to Developing Countries", The Manchester School, Vol.67 No.3, 1999, pp.287-303.

[2] Baharumshah, Ahmad Zubaidi and Mohamed Ariff, "Purchasing Power Parity in South East Asian Countries Economies: A Cointegration Approach", Asian Economic Journal, Vol.11 No.2, 1997, pp.141-153.

[3] Breitung, J. and B. Candelon, "Purchasing power parity during currency crisis: A panel unit root test under structural break". Review of World Economics, 141, 2005, pp.124-40.

[4] Corbae, D. and S. Ouliaris, "Cointegration and tests of purchasing power parity", Review of Economics and Statistics, 3, 1988, pp.508-511.

[5] Davidson, Russell and James G. MacKinnon, Estimation and Inference in Econometrics, Oxford University Press, 1993.

[6] Granger, C. W. J., "Investigating causal relations by econometric models and cross-spectral methods", Econometrica 37,1969.

[7] Hataiseree, Rungsun, "Cointegration Tests of Purchasing Power Parity: the Case of the Thai Baht", Asian Economic Journal, Vol.9 No.1, 1995, pp.57-69.

[8] Johansen, S., Mosconi, R. and B. Nielsen, "Cointegration analysis in the presence of structural breaks in deterministic trends", Econometrics Journal, 3, 2000, pp216-49.

[9] Nusair, S. A., "Testing for PPP in developing countries using confirmatory analysis and different base countries: An application to Asian countries". International Economic Journal, 18, 2004, pp467-89.

[10] Nusair, S. A., "Purchasing Power Parity under Regime Shifts: An Application to Asian Countries". Asian Economic Journal, Vol.22 No.3, 2008, pp.241-266.

[11] Phillips, P. and P. Perron, "Testing for unit root in time series regression", Biometrika, 74, 1988, pp.335-346.

[12] Reinhart, Carmen M., and Kenneth S. Rogoff, "The Modern History of Exchange Rate Arrangements: A Reinterpretation", NBER Working Paper, No. 8963, 2002.

[13] Said, S. and D. A. Dickey, "Testing for unit roots in autoregressive-moving average models of unknown order", Biometrika, 71, 1984, pp.599-607.

[14] Taylor, Mark P., "Purchasing Power Parity", Review of International Economics, 11(3), 2003, pp.436-452.

[15] Zurbruegg, R. and L. Allsopp, "Purchasing power parity and the impact the East Asian currency crisis". Journal of Asian Economics, 15, 2004, pp739-58.

[16] Wu, J. L., Tsai L. J. and Chen, S. L., "Are real exchange rates non-stationary? The Pacific Basin perspective". Journal of Asian Economics, 15, 2004. pp.425-38. 
Table 1-1. The Unit Root Test in the Pre-crisis Period

(1) The real exchange rate on the U.S. dollar base

\begin{tabular}{lccccc}
\hline \hline \multirow{2}{*}{ Variables } & \multicolumn{2}{c}{ ADF Statistic } & \multicolumn{2}{c}{ PP Statistic } & Period \\
& Intercept & Trend \& Intercept & Intercept & Trend \& Intercept & \\
\hline \hline Thailand, WPI & $-2.64^{*}$ & -2.70 & -2.56 & -2.63 & $1957.01-1997.06$ \\
Thailand, CPI & -1.59 & -1.61 & -1.55 & -1.58 & $1965.01-1997.06$ \\
\hline Philippines, WPI & -1.65 & -2.70 & -1.37 & -2.31 & $1993.01-1997.06$ \\
Philippines, CPI & -0.75 & -2.52 & -0.55 & -2.24 & $1985.03-1997.06$ \\
\hline Indonesia, WPI & -1.59 & -1.94 & -1.63 & -2.09 & \\
Indonesia, CPI & -2.60 & -2.59 & -2.66 & -2.39 & $1978.11-1997.07$ \\
\hline Korea, WPI & -0.57 & -0.98 & -0.70 & -1.12 & \\
Korea, CPI & -1.34 & -1.19 & -1.32 & -1.21 & $1974.05-1997.11$ \\
\hline \hline
\end{tabular}

(2) The REER with the world export unit value index

\begin{tabular}{lccccc}
\hline \hline \multirow{2}{*}{ Variables } & \multicolumn{2}{c}{ ADF Statistic } & \multicolumn{2}{c}{ PP Statistic } & Period \\
& Intercept & Trend \& Intercept & Intercept & Trend \& Intercept & \\
\hline \hline Thailand, WPI & -2.09 & -2.82 & -2.04 & -2.73 & $1957.01-1997.06$ \\
Thailand, CPI & -1.11 & -0.38 & -1.09 & -0.33 & $1965.01-1997.06$ \\
\hline Philippines, WPI & -2.06 & $-3.73^{* *}$ & -1.33 & -2.48 & $1993.01-1997.06$ \\
Philippines, CPI & -0.05 & -2.52 & 0.13 & -2.70 & $1985.03-1997.06$ \\
\hline Indonesia, WPI & -1.46 & -1.42 & -1.51 & -1.56 & $1978.11-1997.07$ \\
Indonesia, CPI & $-2.81^{*}$ & -2.47 & $-2.80 *$ & -2.28 & \\
\hline Korea, WPI & -2.49 & -3.00 & -2.53 & -3.03 & $1974.05-1997.11$ \\
Korea, CPI & -1.80 & -2.64 & -1.53 & -2.50 & \\
\hline \hline
\end{tabular}

Notes:

1) The lag truncation is one quarter in the ADF test, and three quarters in the PP test.

2) $* * *, * *$, and $*$ indicate rejection of the null of nonstationarity at the 1 percent, 5

percent, and 10 percent significance levels with critical values taken from Davidson and

MacKinnon (1993).

Source: IFS(IMF) 
Table 1-2. The Unit Root Test in the Post-crisis Period with the Crisis Period

(1) The real exchange rate on the U.S. dollar base

\begin{tabular}{|c|c|c|c|c|c|}
\hline \multirow{2}{*}{ Variables } & \multicolumn{2}{|c|}{ ADF Statistic } & \multicolumn{2}{|c|}{ PP Statistic } & \multirow{2}{*}{ Period } \\
\hline & Intercept & Trend \& Intercept & Intercept & Trend \& Intercept & \\
\hline Thailand, WPI & $-4.09^{* * *}$ & $-4.36^{* * *}$ & $-3.87^{* * *}$ & $-4.14^{* * *}$ & \multirow{2}{*}{ 1997.07-2006.12 } \\
\hline Thailand, CPI & $-5.09^{* * *}$ & $-4.76^{* * *}$ & $-4.71^{* * *}$ & $-4.36^{* * *}$ & \\
\hline Philippines, WPI & $-3.11^{* *}$ & $-4.06^{* * *}$ & -2.48 & $-3.63^{* *}$ & \multirow{2}{*}{ 1997.07-2006.12 } \\
\hline Philippines, CPI & $-3.77^{* * *}$ & -2.79 & $-3.74^{* * *}$ & -2.55 & \\
\hline Indonesia, WPI & $-2.66^{*}$ & $-4.51^{* * *}$ & -2.48 & $-4.23^{* * *}$ & \multirow{2}{*}{ 1997.08-2006.12 } \\
\hline Indonesia, CPI & $-3.29^{* *}$ & $-4.84^{* * *}$ & $-3.04^{* *}$ & $-4.50^{* * *}$ & \\
\hline Korea, WPI & $-3.85^{* * *}$ & $-4.82^{* * *}$ & $-2.61^{*}$ & $-3.69^{* *}$ & \multirow{2}{*}{$1997.12-2006.12$} \\
\hline Korea, CPI & $-2.66^{*}$ & $-5.59^{* * *}$ & -1.61 & $-4.58^{* * *}$ & \\
\hline
\end{tabular}

(2) The REER with the world export unit value index

\begin{tabular}{|c|c|c|c|c|c|}
\hline \multirow{2}{*}{ Variables } & \multicolumn{2}{|c|}{ ADF Statistic } & \multicolumn{2}{|c|}{ PP Statistic } & \multirow{2}{*}{ Period } \\
\hline & Intercept & Trend \& Intercept & Intercept & Trend \& Intercept & \\
\hline Thailand, WPI & $-4.15^{* * *}$ & $-5.97^{* * *}$ & $-3.76^{* * *}$ & $-5.38^{* * *}$ & \multirow{2}{*}{ 1997.07-2006.11 } \\
\hline Thailand, CPI & $-5.63^{* * *}$ & $-5.47^{* * *}$ & $-4.87^{* * *}$ & $-4.71^{* * *}$ & \\
\hline Philippines, WPI & -2.10 & $-3.41^{*}$ & -1.72 & -3.02 & \multirow{2}{*}{ 1997.07-2006.11 } \\
\hline Philippines, CPI & $-3.35^{* *}$ & $-3.40^{*}$ & $-3.14^{* *}$ & -2.91 & \\
\hline Indonesia, WPI & -2.19 & $-3.96^{* *}$ & -1.99 & $-3.69^{* *}$ & \multirow{2}{*}{$1997.08-2006.11$} \\
\hline Indonesia, CPI & $-3.06^{* *}$ & $-4.50^{* * *}$ & $-2.79^{*}$ & $-4.13^{* * *}$ & \\
\hline Korea, WPI & $-3.37^{* *}$ & $-4.60^{* * *}$ & -2.11 & $-3.27^{*}$ & \multirow{2}{*}{ 1997.12-2006.11 } \\
\hline Korea, CPI & $-2.87^{*}$ & $-5.16^{* * *}$ & -1.76 & $-3.74^{* *}$ & \\
\hline
\end{tabular}

Notes:

1) The lag truncation is one quarter in the ADF test, and three quarters in the PP test.

2) $* * *, * *$, and $*$ indicate rejection of the null of nonstationarity at the 1 percent, 5

percent, and 10 percent significance levels with critical values taken from Davidson and

MacKinnon (1993).

Source: IFS(IMF) 
Table 1-3. The Unit Root Test in the Post-crisis Period without the Crisis Period

(1) The real exchange rate on the U.S. dollar base

\begin{tabular}{|c|c|c|c|c|c|}
\hline \multirow{2}{*}{ Variables } & \multicolumn{2}{|c|}{ ADF Statistic } & \multicolumn{2}{|c|}{ PP Statistic } & \multirow{2}{*}{ Period } \\
\hline & Intercept & Trend \& Intercept & Intercept & Trend \& Intercept & \\
\hline Thailand, WPI & $-2.64 *$ & -2.73 & -2.04 & -2.17 & \multirow{2}{*}{$1998.01-2006.12$} \\
\hline Thailand, CPI & $-2.92^{* *}$ & -2.92 & -2.00 & -1.98 & \\
\hline Philippines, WPI & -1.79 & -2.77 & -1.25 & -2.21 & \multirow{2}{*}{ 1997.12-2006.12 } \\
\hline Philippines, CPI & -2.14 & -1.39 & -2.00 & -1.08 & \\
\hline Indonesia, WPI & -1.81 & -2.87 & -1.55 & -2.54 & \multirow{2}{*}{ 1999.04-2006.12 } \\
\hline Indonesia, CPI & -1.62 & -2.71 & -1.26 & -2.25 & \\
\hline Korea, WPI & -1.95 & -2.24 & -1.72 & -1.98 & \multirow{2}{*}{ 1998.07-2006.12 } \\
\hline Korea, CPI & -1.01 & -1.94 & -0.85 & -1.71 & \\
\hline
\end{tabular}

(2) The REER with the world export unit value index

\begin{tabular}{|c|c|c|c|c|c|}
\hline \multirow{2}{*}{ Variables } & \multicolumn{2}{|c|}{ ADF Statistic } & \multicolumn{2}{|c|}{ PP Statistic } & \multirow{2}{*}{ Period } \\
\hline & Intercept & Trend \& Intercept & Intercept & Trend \& Intercept & \\
\hline Thailand, WPI & $-4.43^{* * *}$ & $-5.30^{* * *}$ & $-3.41^{* *}$ & $-3.90^{* *}$ & \multirow{2}{*}{$1998.01-2006.11$} \\
\hline Thailand, CPI & $-5.34^{* * *}$ & $-5.60^{* * *}$ & $-3.89^{* * *}$ & $-4.08^{* * *}$ & \\
\hline Philippines, WPI & -1.62 & -2.36 & -1.27 & -1.98 & \multirow{2}{*}{ 1997.12-2006.11 } \\
\hline Philippines, CPI & -1.97 & -2.30 & -1.72 & -1.84 & \\
\hline Indonesia, WPI & $-2.94^{* *}$ & $-4.09^{* * *}$ & $-2.64^{*}$ & $-3.52^{* *}$ & \multirow{2}{*}{ 1999.04-2006.11 } \\
\hline Indonesia, CPI & $-2.72^{*}$ & $-3.46^{* *}$ & -2.26 & -2.82 & \\
\hline Korea, WPI & $-2.72^{*}$ & -3.05 & -2.52 & -2.74 & \multirow{2}{*}{ 1998.07-2006.11 } \\
\hline Korea, CPI & $-2.84^{*}$ & $-3.84^{* *}$ & $-2.80^{*}$ & $-3.52^{* *}$ & \\
\hline
\end{tabular}

Notes:

1) The lag truncation is one quarter in the ADF test, and three quarters in the PP test.

2) $* * *, * *$, and $*$ indicate rejection of the null of nonstationarity at the 1 percent, 5

percent, and 10 percent significance levels with critical values taken from Davidson and

MacKinnon (1993).

Source: IFS(IMF) 
Table 2. Summary

(1) VAR model for examining the real exchange rate on the U.S. dollar base

\begin{tabular}{lll} 
RER: nul URT $\quad$ ER, RP: nul URT RP $\rightarrow$ ER: G.Cauality RP of ER: V.D. \\
\hline
\end{tabular}

\begin{tabular}{lllcr}
\hline \hline Thailand: WPI & Yes & Yes & Yes & \multicolumn{1}{c}{10.5} \\
Thailand: CPI & Yes & No & - & - \\
Philippines: WPI & Yes & No & - & - \\
Philippines: CPI & Yes & No & - & 1.0 \\
Indonesia: WPI & Yes & Yes & No & 6.4 \\
Indonesia: CPI & Yes & Yes & Yes & 9.6 \\
Korea: WPI & Yes & Yes & Yes & 1.5 \\
Korea: CPI & Yes & Yes & Yes &
\end{tabular}

(2) VAR model for examining the REER with the world export unit value index

REER: nul URT $\quad$ ER, RP: nul URT $\quad$ RP $\rightarrow$ ER: G.Cauality RP of ER: V.D.

\begin{tabular}{llccr}
\hline \hline Thailand: WPI & Yes & Yes & Yes & 22.4 \\
Thailand: CPI & Yes & No & - & - \\
Philippines: WPI & No & - & - & 32.5 \\
Philippines: CPI & Yes & Yes & Yes & 0.1 \\
Indonesia: WPI & Yes & Yes & No & 2.2 \\
Indonesia: CPI & Yes & Yes & No & 10.5 \\
Korea: WPI & Yes & Yes & Yes \\
Korea: CPI & Yes & No & - & - \\
\hline \hline
\end{tabular}

Note: URT: Unit root test, ER: Exchange rate, RP: Relative prices 


\section{Appendix 1. VAR Granger Causality Test}

(1) VAR model for examining the real exchange rate on the U.S. dollar base

\begin{tabular}{lccccc}
\hline \hline & Excluded & Chi-sq & df & Prob. & Sample \\
\hline \hline Thailand, WPI & & & & & \\
Dependent variable ER & RP & 15.04923 & 2 & 0.0005 & $1997.07-2006.12$ \\
Dependent variable RP & ER & 26.56697 & 2 & 0.0000 & \\
\hline \hline Indonesia, WPI & & & & & \\
Dependent variable ER & RP & 3.60174 & 2 & 0.1652 & \multirow{2}{*}{$1997.08-2006.12$} \\
Dependent variable RP & ER & 8.81660 & 2 & 0.0122 & \\
\hline \hline Indonesia, CPI & & & & & \\
Dependent variable ER & RP & 7.53509 & 2 & 0.0231 & \multirow{2}{*}{$1997.08-2006.12$} \\
Dependent variable RP & ER & 66.44645 & 2 & 0.0000 & \\
\hline \hline Korea, WPI & & & & & \\
Dependent variable ER & RP & 11.05745 & 2 & 0.0040 & \multirow{2}{*}{$1997.12-2006.12$} \\
Dependent variable RP & ER & 26.43090 & 2 & 0.0000 & \\
\hline \hline Korea, CPI & & & & & \\
Dependent variable ER & RP & 6.27122 & 2 & 0.0435 & \multirow{2}{*}{$1997.12-2006.12$} \\
Dependent variable RP & ER & 21.39073 & 2 & 0.0000 & \\
\hline \hline
\end{tabular}

(2) VAR model for examining the REER with the world export unit value index

\begin{tabular}{lccccc}
\hline \hline & Excluded & Chi-sq & df & Prob. & Sample \\
\hline \hline Thailand, WPI & & & & & \\
Dependent variable ER & RP & 10.39767 & 2 & 0.0055 & $1997.07-2006.11$ \\
Dependent variable RP & ER & 15.73597 & 2 & 0.0004 & \\
\hline \hline Philippines, CPI & & & & & \\
Dependent variable ER & RP & 16.38257 & 2 & 0.0003 & $1997.07-2006.11$ \\
Dependent variable RP & ER & 0.44132 & 2 & 0.8020 & \\
\hline \hline Indonesia, WPI & & & & & \\
Dependent variable ER & RP & 1.72058 & 2 & 0.4230 & $1997.08-2006.11$ \\
Dependent variable RP & ER & 9.80431 & 2 & 0.0074 & \\
\hline \hline Indonesia, CPI & & & & & \\
Dependent variable ER & RP & 3.62542 & 2 & 0.1632 & $1997.08-2006.11$ \\
Dependent variable RP & ER & 40.66233 & 2 & 0.0000 & \\
\hline \hline Korea, WPI & & & & & \\
Dependent variable ER & RP & 7.53500 & 2 & 0.0231 & \multirow{2}{*}{$1997.12-2006.11$} \\
Dependent variable RP & ER & 20.45069 & 2 & 0.0000 & \\
\hline \hline
\end{tabular}

Notes: ER: Exchange rate, RP: Relative prices

Source: IFS(IMF) 
Appendix 2. Variance Decomposition in VAR Model

(1) VAR model for examining the real exchange rate on the U.S. dollar base

\begin{tabular}{|c|c|c|c|c|}
\hline \multirow{6}{*}{$\begin{array}{c}\text { Thailand, WPI } \\
\text { period } \\
1 \\
5 \\
10 \\
20 \\
\end{array}$} & \multicolumn{2}{|c|}{ ER Variance Decomposition } & \multicolumn{2}{|c|}{ RP Variance Decomposition } \\
\hline & ER & $\mathrm{RP}$ & ER & $\mathrm{RP}$ \\
\hline & 100.0000 & 0.0000 & 13.8528 & 86.1472 \\
\hline & 98.0726 & 0.1977 & 47.4658 & 50.0976 \\
\hline & 91.8950 & 2.6641 & 41.5095 & 51.6662 \\
\hline & 79.2185 & 10.4771 & 34.0287 & 53.4544 \\
\hline Indonesia, WPI & \multicolumn{2}{|c|}{ ER Variance Decomposition } & \multicolumn{2}{|c|}{ RP Variance Decomposition } \\
\hline period & ER & RP & ER & $\mathrm{RP}$ \\
\hline 1 & 100.0000 & 0.0000 & 82.2752 & 17.7248 \\
\hline 5 & 98.9253 & 0.0273 & 93.9272 & 5.9565 \\
\hline 10 & 98.8925 & 0.2422 & 94.5046 & 5.4072 \\
\hline 20 & 98.3313 & 1.0454 & 94.1866 & 5.6265 \\
\hline Indonesia, CPI & \multicolumn{2}{|c|}{ ER Variance Decomposition } & \multicolumn{2}{|c|}{ RP Variance Decomposition } \\
\hline period & ER & $\mathrm{RP}$ & ER & $\mathrm{RP}$ \\
\hline 1 & 100.0000 & 0.0000 & 9.7528 & 90.2472 \\
\hline 5 & 97.1438 & 1.3484 & 63.9848 & 35.2964 \\
\hline 10 & 95.6216 & 3.0980 & 70.0453 & 28.7552 \\
\hline 20 & 92.5160 & 6.3713 & 70.5785 & 27.5167 \\
\hline Korea, WPI & \multicolumn{2}{|c|}{ ER Variance Decomposition } & \multicolumn{2}{|c|}{ RP Variance Decomposition } \\
\hline period & ER & $\mathrm{RP}$ & ER & $\mathrm{RP}$ \\
\hline 1 & 100.0000 & 0.0000 & 21.5151 & 78.4849 \\
\hline 5 & 98.9649 & 0.1790 & 62.0141 & 37.4657 \\
\hline 10 & 94.7643 & 2.2048 & 60.7152 & 38.5072 \\
\hline \multirow{2}{*}{$\begin{array}{r}20 \\
\text { Korea, CPI }\end{array}$} & 86.7732 & 9.5551 & 55.0366 & 44.2116 \\
\hline & \multicolumn{2}{|c|}{ ER Variance Decomposition } & \multicolumn{2}{|c|}{ RP Variance Decomposition } \\
\hline period & ER & $\mathrm{RP}$ & ER & RP \\
\hline 1 & 100.0000 & 0.0000 & 16.7167 & 83.2833 \\
\hline 5 & 98.2300 & 1.2032 & 51.8988 & 46.2306 \\
\hline 10 & 96.8669 & 1.1985 & 51.8584 & 45.0725 \\
\hline 20 & 94.9423 & 1.4858 & 43.3365 & 52.3422 \\
\hline
\end{tabular}

(2) VAR model for examining the REER with the world export unit value index

\begin{tabular}{|c|c|c|c|c|}
\hline \multirow{6}{*}{$\begin{array}{c}\text { Thailand, WPI } \\
\text { period } \\
1 \\
5 \\
10 \\
20\end{array}$} & \multicolumn{2}{|c|}{ ER Variance Decomposition } & \multicolumn{2}{|c|}{ RP Variance Decomposition } \\
\hline & $\mathrm{ER}$ & RP & ER & $\mathrm{RP}$ \\
\hline & 100.0000 & 0.0000 & 28.3864 & 71.6136 \\
\hline & 98.5445 & 1.3997 & 57.3290 & 42.3218 \\
\hline & 90.5908 & 9.3029 & 54.1537 & 45.4031 \\
\hline & 77.4307 & 22.4007 & 49.4416 & 49.8423 \\
\hline Philippines, CPI & \multicolumn{2}{|c|}{ "ER Variance Decomposition } & \multicolumn{2}{|c|}{ RP Variance Decomposition } \\
\hline period & ER & RP & ER & $\mathrm{RP}$ \\
\hline 1 & 100.0000 & 0.0000 & 4.4836 & 95.5164 \\
\hline 5 & 95.9686 & 1.3282 & 3.9300 & 95.8734 \\
\hline 10 & 87.4273 & 8.9004 & 2.6770 & 96.9797 \\
\hline \multirow{2}{*}{$\frac{20}{\text { Indonesia, WPI }}$} & 64.8931 & 32.4896 & 1.4694 & 97.9463 \\
\hline & \multicolumn{2}{|c|}{ ER Variance Decomposition } & \multicolumn{2}{|c|}{ RP Variance Decomposition } \\
\hline period & ER & RP & ER & $\mathrm{RP}$ \\
\hline 1 & 100.0000 & 0.0000 & 80.5931 & 19.4069 \\
\hline 5 & 99.1539 & 0.1534 & 94.9398 & 5.0147 \\
\hline 10 & 99.3945 & 0.0926 & 96.8451 & 3.0039 \\
\hline & 99.5961 & 0.0852 & 97.9761 & 1.8251 \\
\hline $\begin{array}{c}\begin{array}{c}\text { Indonesia, CPI } \\
\text { period }\end{array} \\
\end{array}$ & \multicolumn{2}{|c|}{ ER Variance Decomposition } & \multicolumn{2}{|c|}{ RP Variance Decomposition } \\
\hline period & ER & RP & ER & $\mathrm{RP}$ \\
\hline 1 & 100.0000 & 0.0000 & 23.3673 & 76.6327 \\
\hline 5 & 98.8144 & 0.4622 & 74.8545 & 24.7917 \\
\hline 10 & 98.4357 & 1.0774 & 84.8014 & 14.6871 \\
\hline 20 & 97.4026 & 2.2036 & 89.4232 & 10.0315 \\
\hline \multirow{2}{*}{$\begin{array}{l}\text { Korea, WPI } \\
\text { period }\end{array}$} & \multicolumn{2}{|c|}{ ER Variance Decomposition } & \multicolumn{2}{|c|}{ RP Variance Decomposition } \\
\hline & ER & $\mathrm{RP}$ & ER & $\mathrm{RP}$ \\
\hline 1 & 100.0000 & 0.0000 & 20.8375 & 79.1625 \\
\hline 5 & 99.6797 & 0.2838 & 58.5468 & 41.3456 \\
\hline 10 & 97.4428 & 2.4137 & 58.2505 & 41.6956 \\
\hline 20 & 89.3846 & 10.4622 & 53.3459 & $\begin{array}{r}46.6225 \\
\end{array}$ \\
\hline
\end{tabular}

Notes: ER: Exchange rate, RP: Relative prices

Source: IFS(IMF) 
Appendix 3. Impulse Response of Exchange Rate to Shock in Relative Prices

\section{(1) Real Exchange Rate}
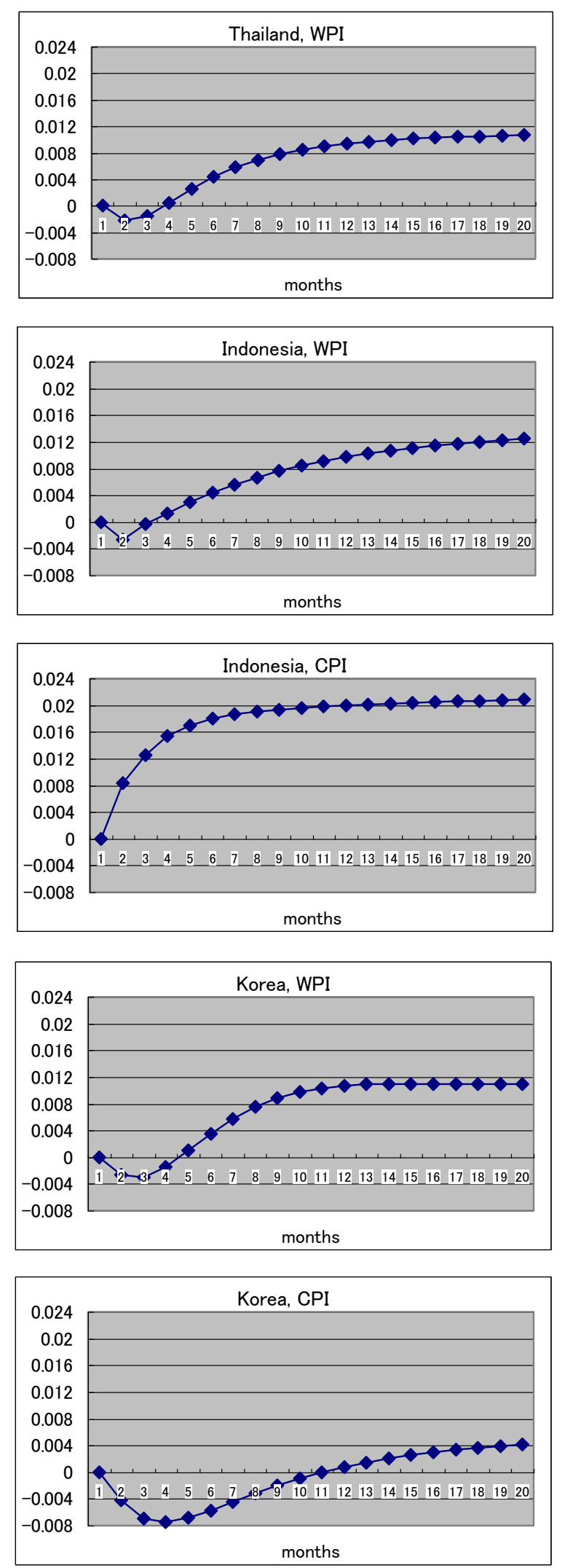

Source: IFS(IMF)
(2) REER
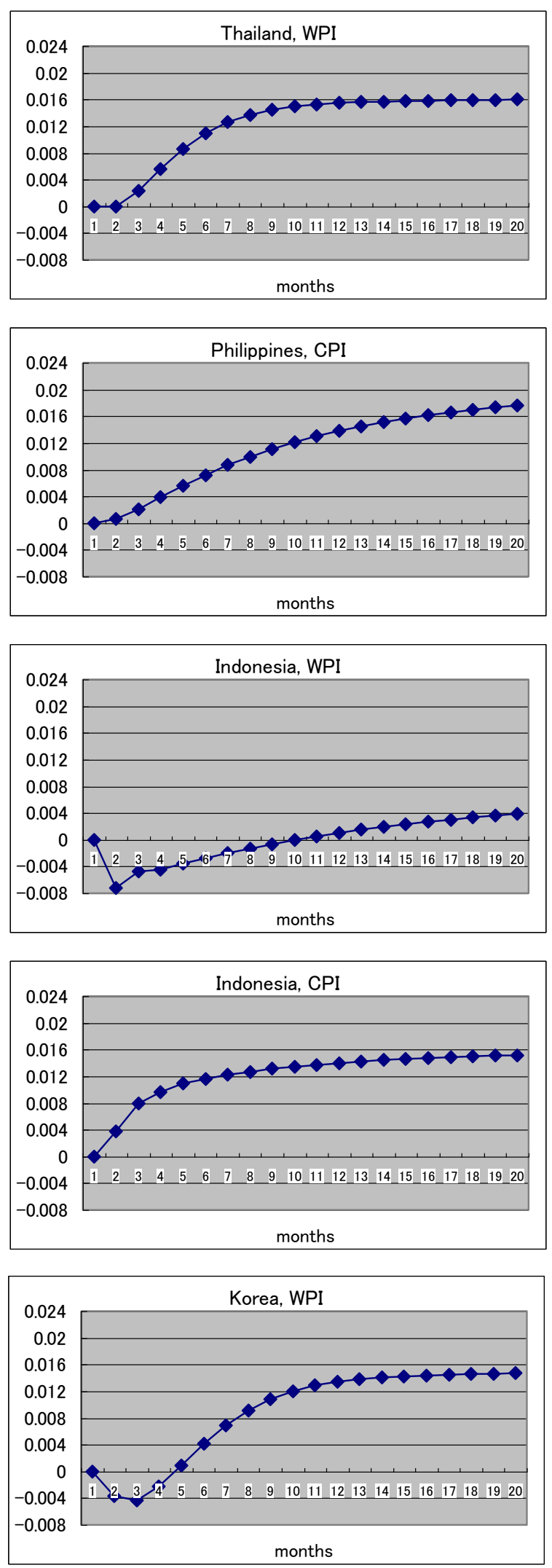


\section{Notes}

1. The difference in the results might come from the difference in the post-crisis estimation periods; Kawai [9] (2002) estimates from January 1999 to June 2002 as the post-crisis period, while McKinnon [10] (2001) does from January 1999 to May 2000. In the estimate of Kawai [9] (2002), the significant weight-shifts from the US dollar to the Japanese yen in Korea and Thailand are identified mainly after July 2000, which is beyond the estimate period of McKinnon [10] (2001).

2. The IMF classification of exchange rate arrangements did not necessarily reflect actual exchange rate management, since it was based on member countries' formally announced regimes. For example, the pre-crisis exchange rate arrangements of Indonesia, Korea, and Malaysia were classified as "Managed Float," for the Philippines it was "Independent Float," and for Thailand the classification was "Pegged to Currency Composite," although all of them appeared to have adopted the dollar peg regime. Many economists, therefore, have presented their own analysis of the de facto exchange rate regimes. We here follow the analysis presented by Reinhart and Rogoff [12] (2002).

3. The IMF weights, which are derived from the Multilateral Exchange Rate Model (MERM), represent the model's estimate of the effect on the trade balance of the country in question of a one percent change in the domestic currency price of each of the other currencies. A detail description of the method is contained in the IFS Supplement on Exchange Rates, No.9 (1985).

4. In this section, exchange rate is expressed as units of local currency per U.S. dollar.

5. It is true that even during the post-crisis period alone (without the crisis period) the stationarity of the REER in some cases was also identified in the previous section. There was, however no case where the stationarity of exchange rate and relative prices was verified for constructing a VAR model for examining the REER. We, therefore, focused on only the cases during the combined crisis and post-crisis period for the VAR model analyses. 